\title{
Micro-aggregates do not influence bone marrow stromal cell chondrogenesis
}

Citation for published version (APA):

Potier, E., Rivron, N. C., Van Blitterswijk, C. A., \& Ito, K. (2016). Micro-aggregates do not influence bone marrow stromal cell chondrogenesis. Journal of Tissue Engineering and Regenerative Medicine, 10(12), 1021-1032. https://doi.org/10.1002/term.1887

Document status and date:

Published: 01/12/2016

DOI:

10.1002/term.1887

Document Version:

Publisher's PDF, also known as Version of record

Document license:

Taverne

Please check the document version of this publication:

- A submitted manuscript is the version of the article upon submission and before peer-review. There can be important differences between the submitted version and the official published version of record.

People interested in the research are advised to contact the author for the final version of the publication, or visit the DOI to the publisher's website.

- The final author version and the galley proof are versions of the publication after peer review.

- The final published version features the final layout of the paper including the volume, issue and page numbers.

Link to publication

\footnotetext{
General rights rights.

- You may freely distribute the URL identifying the publication in the public portal. please follow below link for the End User Agreement:

www.umlib.nl/taverne-license

Take down policy

If you believe that this document breaches copyright please contact us at:

repository@maastrichtuniversity.nl

providing details and we will investigate your claim.
}

Copyright and moral rights for the publications made accessible in the public portal are retained by the authors and/or other copyright owners and it is a condition of accessing publications that users recognise and abide by the legal requirements associated with these

- Users may download and print one copy of any publication from the public portal for the purpose of private study or research.

- You may not further distribute the material or use it for any profit-making activity or commercial gain

If the publication is distributed under the terms of Article $25 \mathrm{fa}$ of the Dutch Copyright Act, indicated by the "Taverne" license above, 


\title{
Micro-aggregates do not influence bone marrow stromal cell chondrogenesis
}

\author{
E. Potier ${ }^{1}$, N. C. Rivron ${ }^{2}$, C. A. Van Blitterswijk ${ }^{2}$ and K. Ito ${ }^{1 *}$ \\ ${ }^{1}$ Orthopaedic Biomechanics, Department of Biomedical Engineering, Eindhoven University of Technology, Eindhoven, The Netherlands \\ ${ }^{2}$ Department of Tissue Regeneration, MIRA Institute for Biomedical Technology and Technical Medicine, University of Twente, Enschede, \\ The Netherlands
}

\begin{abstract}
Although bone marrow stromal cells (BMSCs) appear promising for cartilage repair, current clinical results are suboptimal and the success of BMSC-based therapies relies on a number of methodological improvements, among which is better understanding and control of their differentiation pathways. We investigated here the role of the cellular environment (paracrine vs juxtacrine signalling) in the chondrogenic differentiation of BMSCs. Bovine BMSCs were encapsulated in alginate beads, as dispersed cells or as small micro-aggregates, to create different paracrine and juxtacrine signalling conditions. BMSCs were then cultured for 21 days with TGF $\beta_{3}$ added for 0,7 or 21 days. Chondrogenic differentiation was assessed at the gene (type II and X collagens, aggrecan, TGF $\beta$, sp7) and matrix (biochemical assays and histology) levels. The results showed that micro-aggregates had no beneficial effects over dispersed cells: matrix production was similar, whereas chondrogenic marker gene expression was lower for the micro-aggregates, under all TGF $\beta$ conditions tested. This weakened chondrogenic differentiation might be explained by a different cytoskeleton organization at day 0 in the micro-aggregates. Copyright (c) 2014 John Wiley \& Sons, Ltd.
\end{abstract}

Received 3 May 2013; Revised 4 November 2013; Accepted 24 February 2014

Keywords bone marrow stromal cells; mesenchymal stem cells; chondrogenesis; cell-cell interactions; micro-aggregates; hydrogel

\section{Introduction}

Articular hyaline cartilage only possesses a limited self-repair capacity. Most tissue damage, caused either by wear and tear or trauma, will not be healed but replaced by fibrocartilage. This tissue has inferior biochemical and biomechanical properties compared to native hyaline cartilage, altering the function of the joint and ultimately leading to severe pain (Ahmed and Hincke, 2010; Nesic et al., 2006). Surgical approaches are commonly proposed to promote the healing of cartilage damage. They present, however, several limitations linked to the cell/tissue source and may lead to the formation of fibrocartilage rather than hyaline cartilage (Ahmed and Hincke, 2010;

*Correspondence to: K. Ito, Orthopaedic Biomechanics, Department of Biomedical Engineering, Eindhoven University of Technology, PO Box 513, GEM-Z 4.115, 5600 MB Eindhoven, The Netherlands.E-mail: k.ito@tue.nl
Khan et al., 2010). Alternative sources of cells/tissues are therefore needed to regenerate cartilage damage.

One of the most promising sources is bone marrow stromal cells (BMSCs) (Gregory et al., 2005; Khan et al., 2010; Krampera et al., 2006; Prockop, 1997). As these cells are isolated from the bone marrow, no cartilage tissue harvesting is required and the tissue source is exempt from degenerative cartilage disease. BMSCs also possess a high proliferative rate, allowing the regeneration of large defects. Many studies have established that BMSCs can differentiate in vitro into chondrocytes (Muraglia et al., 2000; Halleux et al., 2001; Pittenger et al., 1999). The patient's condition can affect BMSC proliferation and differentiation: age and osteoarthritis have been reported to reduce the chondrogenic potential of BMSCs (Murphy et al., 2002); although other studies report that these factors do not influence BMSC chondrogenesis (Dudics et al., 2009; Scharstuhl et al., 2007). BMSCs have been used to repair cartilage lesions in numerous animal models 
(Guo et al., 2004; Uematsu et al., 2005) but also in humans (Wakitani et al., 2002; Nejadnik et al., 2010). Although the results are promising, the repair tissues were not completely composed of hyaline cartilage (Matsumoto et al., 2010). However, it is the general belief that, with further advancements, BMSC-based therapies will eventually be helpful in clinics.

One important direction for improvement is to better understand and control the differentiation pathway leading BMSCs to fully differentiated and functional chondrocytes. For many years, BMSC differentiation has been induced by various cocktails of biochemical factors (Augello and De, 2010) and more and more evidence indicates that their biomechanical environment can control their differentiation (Potier et al., 2010). Other than applied exogenous stimulation, direct communication of cells with their environment can also affect their behaviour. For example, cells can respond to different substrate stiffness, for BMSCs, by adapting their differentiation pathways (Engler et al., 2006; Pek et al., 2010) or, for chondrocytes, their chondrogenic phenotype (Sanz-Ramos et al., 2013; Schuh et al., 2010). However, so far, few studies have focused on the relationship between cell-cell communication and BMSC differentiation, when adhesion of cells to each other may also provide important clues to control BMSCs, as shown with the osteogenic differentiation pathway (Tang et al., 2010).

The aim of this study was, therefore, to modulate the cell-cell interactions between BMSCs and evaluate the impact on BMSC in vitro chondrogenesis. In order to create different cell-cell interactions, BMSCs were seeded into hydrogel either as dispersed cells, where interactions rely on paracrine signalling, or as microaggregates, where interactions rely on paracrine and juxtacrine signalling. Micro-aggregates, rather than micromass, were used to promote cell-cell contact locally. Indeed, it has been shown that micromass culture, used to mimic the condensation phenomenon of mesenchymal cells during development (Bobick et al., 2009), leads to heterogeneous distribution of the cartilaginous matrix (Barry et al., 2001; Mackay et al., 1998; Schmitt et al., 2003; Murdoch et al., 2007), most likely due to mass transport limitations within the micromass. Downscaling from micromass (200 000-250 000 cells) to micro-aggregates (50-300 cells) should overcome these mass transport issues. In fact, micro-aggregate culture has already been shown to be superior to micromass for BMSC chondrogenesis, with a more homogeneous differentiation and matrix deposition observed (Markway et al., 2010). Finally, the effects of cell-cell interactions on BMSC chondrogenesis could be attenuated by the presence of exogenous growth factors (e.g. $\mathrm{TGF} \beta_{3}$ ) in the culture medium. We therefore used different patterns of TGF $\beta$ stimulation ( 0,7 or 21 days) to assess the influence of different cellular environments [dispersed cells (DC) vs micro-aggregates (MA)] on BMSC chondrogenesis.

\section{Materials and methods}

\subsection{Bovine BMSC isolation and expansion}

Bovine BMSCs were isolated from three cows (8-12 months old, all skeletally immature), in accordance with local regulations. Bone marrow was aspirated from the pelvis and immediately mixed 1:1 with high-glucose (4.5 g/l) Dulbecco's modified Eagle's medium (hgDMEM; Gibco Invitrogen, Carlsbad, CA, USA) supplemented with $100 \mathrm{U} / \mathrm{ml}$ heparin (Sigma, Zwijndrecht, The Netherlands) and 3\% penicillin-streptomycin (Lonza, Basel, Switzerland). Bone marrow samples were then centrifuged $(300 \times g, 5 \mathrm{~min})$ and resuspended in growth medium: hgDMEM $+10 \%$ fetal bovine serum (FBS; Gibco Invitrogen; batch selected for BMSC growth and differentiation) $+1 \%$ penicillin-streptomycin. BMSCs were isolated by adhesion (Friedenstein et al., 1970; Kon et al., 2000; Potier et al., 2007). Cells were seeded in flasks (using 7-10 ml medium:bone marrow mix per $75 \mathrm{~cm}^{2}$ ) and, after 4 days, the medium was changed. BMSCs were then expanded up to P1 (passage at 5000 cells $/ \mathrm{cm}^{2}$ ) before freezing [70-80\% confluence; in $90 \% \mathrm{FBS} / 10 \%$ dimethylsulphoxide (Sigma)]. A fresh batch of BMSCs was thawed and cultured up to P4 for each experiment (each passage at 5000 cells $/ \mathrm{cm}^{2}$ ). Cells from each donor were cultured separately. Bovine BMSCs $(n=4)$ isolated and expanded following these protocols showed successful chondrogenesis using the micromass approach (Johnstone et al., 1998) (as shown with safranin $\mathrm{O}$ staining).

\subsection{Production of agarose chips}

Custom-made PDMS stamps, with a microstructured surface consisting of 2865 rounded pins with a diameter of $200 \mu \mathrm{m}$ and a spacing of $100 \mu \mathrm{m}$, were produced. The stamps were sterilized with alcohol and placed in a sixwell plate, microstructured surface up. Warm ultra-pure agarose solution [Gibco Invitrogen; 3\% in phosphate-buffered saline (PBS)] was poured on the stamps, centrifuged for $1 \mathrm{~min}$ at $2500 \mathrm{rpm}$ and incubated for $30 \mathrm{~min}$ at $4^{\circ} \mathrm{C}$. The agarose chips were then separated from the stamps, cut to size to fit in a well of a 12 -well plate, covered with PBS and kept at $4^{\circ} \mathrm{C}$ until use (Rivron et al., 2012).

\subsection{Formation of micro-aggregates and alginate seeding}

At passage 5, BMSCs were used to seed: (a) alginate beads (dispersed cells; DC); or (b) agarose chips (microaggregates; MA) (Figure 1). For the DC condition, BMSCs were resuspended in $1.2 \%$ sodium alginate (Sigma) solution (in 0.9\% NaCl; Merck, Darmstadt, Germany) at a concentration of $7 \times 10^{6}$ cells $/ \mathrm{ml}$. The cell + alginate suspension was slowly forced through a $22 \mathrm{G}$ needle and added dropwise to a $102 \mathrm{mM} \mathrm{CaCl}_{2}$ (Merck) solution 


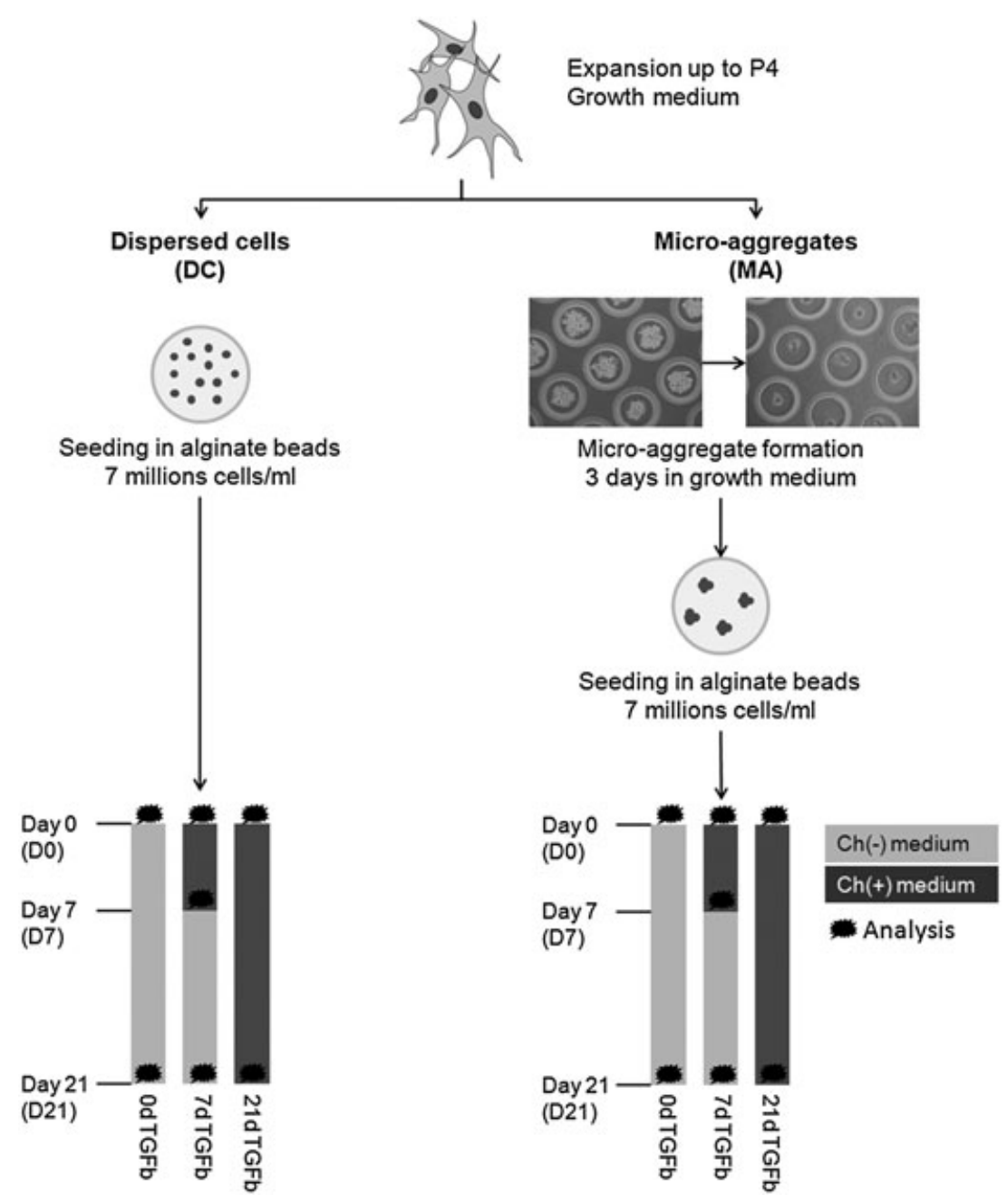

Figure 1. Experimental design. Bovine BMSCs $(n=3)$ were expanded up to P4 in hgDMEM $+10 \% \mathrm{FBS}+1 \% \mathrm{P} / \mathrm{S}$ (growth medium). Cells were then used to seed either alginate beads at 7 million cells/ml (dispersed cells; DC) or agarose chips cast on PDMS stamps (micro-aggregates; MA). BMSCs on agarose chips were cultured for 3 additional days in growth medium to allow the cells to form micro-aggregates. Those were then used to seed alginate beads at 7 million cells/ml. After seeding in alginate, BMSCs (DC or MA) were cultured for 3 weeks in hgDMEM $+1 \% \mathrm{P} / \mathrm{S}+0.1 \mu \mathrm{M}$ dexamethasone $+1 \% \mathrm{ITS}-1^{+}+1.25 \mathrm{mg} / \mathrm{ml} \mathrm{BSA}+50 \mu \mathrm{g} / \mathrm{ml}$ ascorbic acid 2-phosphate $+40 \mu \mathrm{g} / \mathrm{ml} \mathrm{L}$-proline $+100 \mu \mathrm{g} / \mathrm{ml}$ sodium pyruvate $\left(\mathrm{Ch}^{-}\right.$medium). This medium was supplemented with $10 \mathrm{ng} / \mathrm{ml} \mathrm{TGF}_{3}\left(\mathrm{Ch}^{+}\right.$ medium) for 0,7 or 21 days. At D0 and D21, cell viability was characterized by live/dead staining; cell morphology by histology (phalloidin, anti-vinculin and anti-pan-cadherin staining); produced matrix by histology (Alcian blue staining); biochemical assays [glycosaminoglycan (GAG) and DNA content]; and cell phenotype was characterized by qRT-PCR (types II and X collagens, sox9, aggrecan, TGF $\beta$ and sp7)

(Guo et al., 1989; Jonitz et al., 2011). Beads were incubated for $10 \mathrm{~min}$ at $37^{\circ} \mathrm{C}$ to polymerize and were then rinsed three times in $\mathrm{NaCl} 0.9 \%$ and twice in hgDMEM $+1 \%$ penicillin-streptomycin. For the MA condition, BMSCs were resuspended in growth medium at $2 \times 10^{5}$ cells/ml and $750 \mu \mathrm{l}$ cell suspension was used per agarose chip (with PBS previously removed) to produce the microaggregates. Seeded chips were centrifuged for $1 \mathrm{~min}$ at $200 \times g$ to force the cells to the bottom of the microwells; $3 \mathrm{ml}$ growth medium was then slowly added and the cells were cultured for an additional 3 days in growth medium to allow cell aggregation. Micro-aggregates were then collected, flushing the agarose chips with growth medium, and used to seed alginate beads at a final concentration of $7 \times 10^{6}$ cells $/ \mathrm{ml}$, as described for the DC condition.

\subsection{Culture}

Seeded beads (with either DC or MA) were cultured for 3 weeks in $\mathrm{Ch}^{-}$medium [hgDMEM $+1 \%$ penicillin-streptomycin $+0.1 \mu \mathrm{M}$ dexamethasone $($ Sigma $)+1 \%{\text { ITS }-1^{+}}^{+}$ (Sigma) $+1.25 \mathrm{mg} / \mathrm{ml}$ bovine serum albumin (BSA; Sigma) $+50 \mu \mathrm{g} / \mathrm{ml}$ ascorbic acid 2-phosphate (Sigma) $+40 \mu \mathrm{g} / \mathrm{ml} \mathrm{L-proline} \mathrm{(Sigma)} \mathrm{+} 100 \mu \mathrm{g} / \mathrm{ml}$ sodium pyruvate (Gibco Invitrogen)] (Mackay et al., 1998). This medium was supplemented with $10 \mathrm{ng} / \mathrm{ml}$ (TGF $\beta_{3}$; (Peprotech, Rocky Hill, NJ, USA) (Barry et al., 2001) (Ch(+) medium) for 0,7 or 21 days (Figure 1). BMSCs were cultured under $5 \% \mathrm{CO}_{2}$ and $2 \% \mathrm{O}_{2}$ (Markway et al., 2010); six beads/well, of a six-well plate containing $3 \mathrm{ml}$ medium, were cultured. 


\subsection{Cell viability}

At days 0 and 21, beads ( $n=3$ beads/donor/group) were washed in PBS and incubated in $10 \mu \mathrm{M}$ calcein AM (Sigma)/10 $\mu \mathrm{M}$ propidium iodide (Gibco Invitrogen) solution (in PBS) for $1 \mathrm{~h}$ at $37^{\circ} \mathrm{C}$. Cells were then imaged in the centres of the beads at a depth of $200 \mu \mathrm{m}$, using a confocal microscope (CLSM 510 Meta, Zeiss, Sliedrecht, The Netherlands).

\subsection{Cell morphology and adhesion}

At days 0 and 21, beads ( $n=3$ beads/donor/group) were embedded in cryo-compound (Tissue-Tek ${ }^{\circledR}$ OCT $^{\mathrm{TM}}$; Sakura, Alphen aan den Rijn, The Netherlands) and snap-frozen in liquid nitrogen; $50 \mu \mathrm{m}$-thick cryosections were cut in the middle of the beads. The sections were then thawed, fixed for $30 \mathrm{~min}$ at room temperature (RT) in buffered formalin 3.7\% (Merck), rinsed in PBS and incubated for $5 \mathrm{~min}$ at RT in Triton $1.5 \%$ in PBS. The sections were rinsed in PBS and stained with TRITCphalloidin (Sigma; $1 \mu \mathrm{M}$ in PBS $+1 \% \mathrm{BSA}$ ) for $2 \mathrm{~h}$ at RT. The sections were then rinsed in PBS, counterstained with DAPI for $15 \mathrm{~min}$ at RT (Sigma; $100 \mathrm{ng} / \mathrm{ml}$ in PBS), rinsed in PBS and MilliQ water, air-dried and mounted in Entellan (Merck). The stained sections were observed using a confocal microscope.

Morphometric analyses to determine cluster areas and numbers of cells/cluster were conducted on these images, using Zen 2012 software (Zeiss). For each group, 25 clusters or cells were analysed. Stained clusters or cells were manually outlined and the corresponding area determined. Cell numbers/cluster were also counted manually.

Immunostaining for vinculin and pan-cadherin was conducted on $10 \mu \mathrm{m}$-thick cryosections. The sections were thawed, fixed for $10 \mathrm{~min}$ at RT in buffered formalin $3.7 \%$, rinsed in PBS and incubated for $10 \mathrm{~min}$ at RT in Triton $0.5 \%$ in PBS. After blocking in 3\% BSA for $1 \mathrm{~h}$, the sections were incubated for $1 \mathrm{~h}$ at RT with monoclonal mouse anti-vinculin antibodies (Sigma), diluted at 1:400, or with monoclonal mouse anti-cadherin antibodies (Abcam; Cambridge, UK), diluted at 1:100, in $3 \%$ BSA. The sections were then washed three times in PBS and incubated for $1 \mathrm{~h}$ at $38^{\circ} \mathrm{C}$ with Alexa 488-conjugated goat anti-mouse antibodies (Molecular Probes; Bleiswijk, The Netherlands), diluted 1:300 in PBS. The stained sections were then rinsed three times and mounted with Mowiol. For both stainings, human cardiomyocyte progenitor cells grown on coverslips were used as a positive control. Both antibodies are known to work with bovine material.

\subsection{Cartilaginous matrix formation and cell proliferation}

At days 0 and 21, five beads/donor and group were pooled and digested in papain solution [150 mM
$\mathrm{NaCl}$ (Merck), $789 \mu \mathrm{g} / \mathrm{ml}$ L-cysteine (Sigma), $5 \mathrm{~mm}$ $\mathrm{Na}_{2}$ EDTA $2 \mathrm{H}_{2} \mathrm{O}$ (Sigma), $55 \mathrm{~mm} \mathrm{Na}{ }_{3}$ citrate $2 \mathrm{H}_{2} \mathrm{O}$ (Sigma) and $125 \mu \mathrm{g} / \mathrm{ml}$ papain (Sigma)] at $60^{\circ} \mathrm{C}$ for $16 \mathrm{~h}$. Digested samples were then used to determine their content of sulphated glycosaminoglycans (sGAG), as a measure of proteoglycans, and DNA. sGAG content was determined using the dimethyl methylene blue (DMMB) assay, adapted for alginate presence (Enobakhare et al., 1996). Shark cartilage chondroitin sulphate (Sigma) was used as a reference and digested with empty alginate beads (i.e. alginate concentration identical for references and experimental samples). DNA content was measured using the Hoechst dye method (Cesarone et al., 1979), with a calf thymus DNA reference (Sigma). For the 7 days of $\mathrm{TGF} \beta_{3}$-treatment group, the beads were also analysed at day 7.

At days 0 and 21, beads ( $n=3$ beads/donor/group) were also embedded in cryo-compound and snap-frozen in liquid nitrogen. $10 \mu \mathrm{m}$ thick cryosections were cut in the middle of the beads. The sections were then thawed, incubated for $5 \mathrm{~min}$ in $0.1 \mathrm{M} \mathrm{CaCl}_{2}$ at RT and fixed in buffered formalin $3.7 \%$ for $3 \mathrm{~min}$ at RT. The sections were then rinsed in 3\% glacial acetic acid (Merck) and stained in Alcian blue solution (Sigma; 1\%, pH 1.0, for alginate presence) for $30 \mathrm{~min}$ at $37^{\circ} \mathrm{C}$. The sections were then rinsed in $0.05 \mathrm{M} \mathrm{CaCl}_{2}$ and counterstained with nuclear fast red solution (Sigma) for $7 \mathrm{~min}$ at RT. The stained sections were rinsed in $0.05 \mathrm{M} \mathrm{CaCl}_{2}$ before mounting in Mowiol (Merck) and were observed using a brightfield microscope (Observer Z1, Zeiss).

\subsection{Gene expression}

At days 0 and 21, nine beads/donor and group were pooled, snap-frozen in liquid nitrogen and stored at $80^{\circ} \mathrm{C}$ until RNA isolation. Frozen beads were placed in between a 316 SS $8 \mathrm{~mm}$ bead and a custom-made lid, placed in a $2 \mathrm{ml}$ Eppendorf tube, and were disrupted for $30 \mathrm{~s}$ at $1500 \mathrm{rpm}$ (Micro-dismembrator; Sartorius, Göttingen, Germany). RNA was then extracted using TRIzol $^{\circledR}$ (Gibco Invitrogen) and purified using an RNeasy mini-kit (Qiagen, Venlo, The Netherlands). The quantity and purity of the isolated RNA were measured by spectrophotometry (ND-1000, Isogen, De Meern, The Netherlands) and integrity by gel electrophoresis. Absence of genomic DNA was validated by end-point PCR and gel electrophoresis using primers for glyceraldehyde 3-phosphate dehydrogenase (GAPDH).

Total RNA (300 ng) was then reverse-transcribed (M-MLV; Gibco Invitrogen) and the gene expression levels of sox9, aggrecan, type II collagen, TGF $\beta$, type X collagen and sp7 (also known as Osterix) were assessed with SYBR green qPCR (iCycler; Biorad, Hercules, CA, USA) (see Table 1 for primer list). $18 S$ (PrimerDesign Ltd, Southampton, UK) was selected as a reference gene from three genes (RPL13A, GAPDH and 18S) as the most stable gene throughout our experimental conditions. Expression 
Table 1. Primer sequences for target and reference genes used in RT-qPCR assays

\begin{tabular}{|c|c|c|c|c|}
\hline Gene & Accession No.* & Sequence 5'-3' & Product size (bp) & Source** \\
\hline RPL13a & NM_001076998 & $\begin{array}{l}\text { CTGCCCCACAAGACCAAG } \\
\text { TTGCGAGTAGGCTTCAGAC }\end{array}$ & 140 & BD \\
\hline GAPDH & NM_001034034 & $\begin{array}{l}\text { GGCGTGAACCACGAGAAGTATAA } \\
\text { CCCTCCACGATGCCAAAGT }\end{array}$ & 119 & van Dijk et al. (2011) \\
\hline SOX9 & AF278703 & $\begin{array}{l}\text { ACGCCGAGCTCAGCAAGA } \\
\text { CACGAACGGCCGCTTCT }\end{array}$ & 70 & Shintani et al. (2007) \\
\hline COL2A1 & NM_001113224 & $\begin{array}{l}\text { TGGCTGACCTGACCTGAC } \\
\text { GGGCGTTTGACTCACTCC }\end{array}$ & 187 & BD \\
\hline$A C A N$ & NM_173981 & $\begin{array}{l}\text { CCAACGAAACCTATGACGTGTACT } \\
\text { GCACTCGTTGGCTGCCTC }\end{array}$ & 107 & Zeiter et al. (2009) \\
\hline TGFB1 & NM_001166068 & $\begin{array}{l}\text { CTGAGCCAGAGGCGGACTAC } \\
\text { TTGCTGAGGTAGCGCCAGGAATTG }\end{array}$ & 259 & Karcher et al. (2008) \\
\hline COL10A1 & NM_174634 & $\begin{array}{l}\text { TGAGCGATACCAAACACCTACAG } \\
\text { ACCTTTACCCTTTATGGCATACGG }\end{array}$ & 91 & BD \\
\hline SP7 & NM_001102142 & $\begin{array}{l}\text { CAAAGCAGGCACAAAGAAG } \\
\text { GAGGGTAGTCATTGGCATAG }\end{array}$ & 161 & BD \\
\hline
\end{tabular}

RPL13a, ribosomal protein L13a; GAPDH, glyceraldehyde-3-phosphate dehydrogenase; SOX9, SRY (sex determining region Y)-box 9; COL2A1, collagen type II $\alpha 1$; ACAN, aggrecan; TGFB1, transforming growth factor- $\beta 1$; COL10A1, collagen type X $\alpha 1$; SP7, Sp7 transcription factor.

${ }^{*}$ GenBank ${ }^{\mathrm{T}}$ accession number.

**BD, primers designed with Beacon designer software (Premier Biosoft, Palo Alto, CA, USA) and ordered from Sigma.

of the gene of interest is reported as relative to $18 \mathrm{~S}$ expression ( $2^{-\triangle \mathrm{CT}}$ method). When gene expression was not detected, the $2^{-\triangle \mathrm{CT}}$ value was set to 0 to conduct the statistical analysis. For the 7 days of $\mathrm{TGF} \beta_{3}$ treatment group, beads were also analysed at day 7 .

\subsection{Statistical analysis}

General linear regression models based on ANOVAs were used to examine the effects of seeding (DC and MA), TGF $\beta$ treatment (0, 7 and 21 days) and days of culture
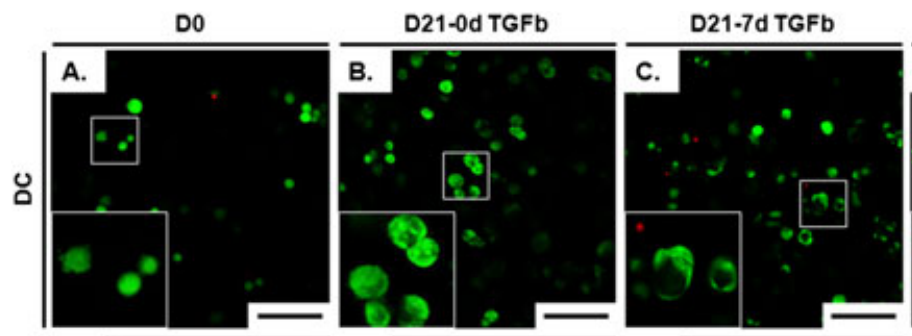

D21-21d TGFb
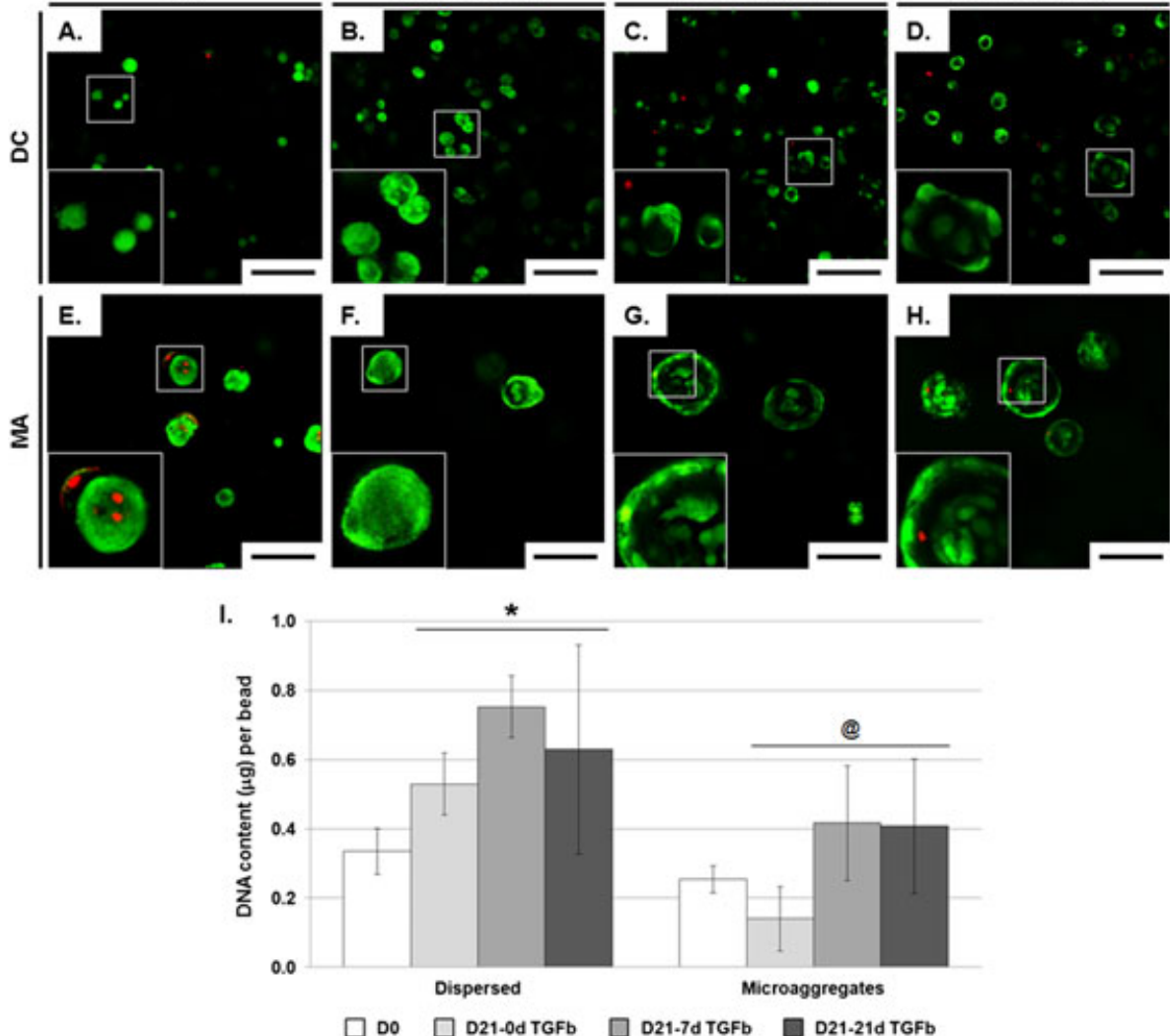

Figure 2. Cell viability and proliferation. (A-H) Bovine BMSCs seeded in alginate beads as dispersed cells (A-D) or as micro-aggregates (E-H) at days $0(\mathrm{~A}, \mathrm{E})$ and 21 after exposure to TGF $\beta_{3}$ for $\mathbf{0}(\mathrm{B}, \mathrm{F}), 7(\mathrm{C}, \mathrm{G})$, and 21 (D, H) days. Cells were stained with calcein AM (green fluorescence) for living cells and propidium iodide (red fluorescence) for dead cells. White frames are $\times 2.5$ digital magnification; representative of three donors/group; scale bar $=100 \mu \mathrm{m}$; colour images are available online. (I) DNA content/bead, as determined with Hoechst dye assay; values are mean $\pm \mathrm{SD} ; n=3$ /group. ${ }^{*} p<0.05$ vs D0; ${ }^{\circledR} p<0.05$ vs dispersed cells 

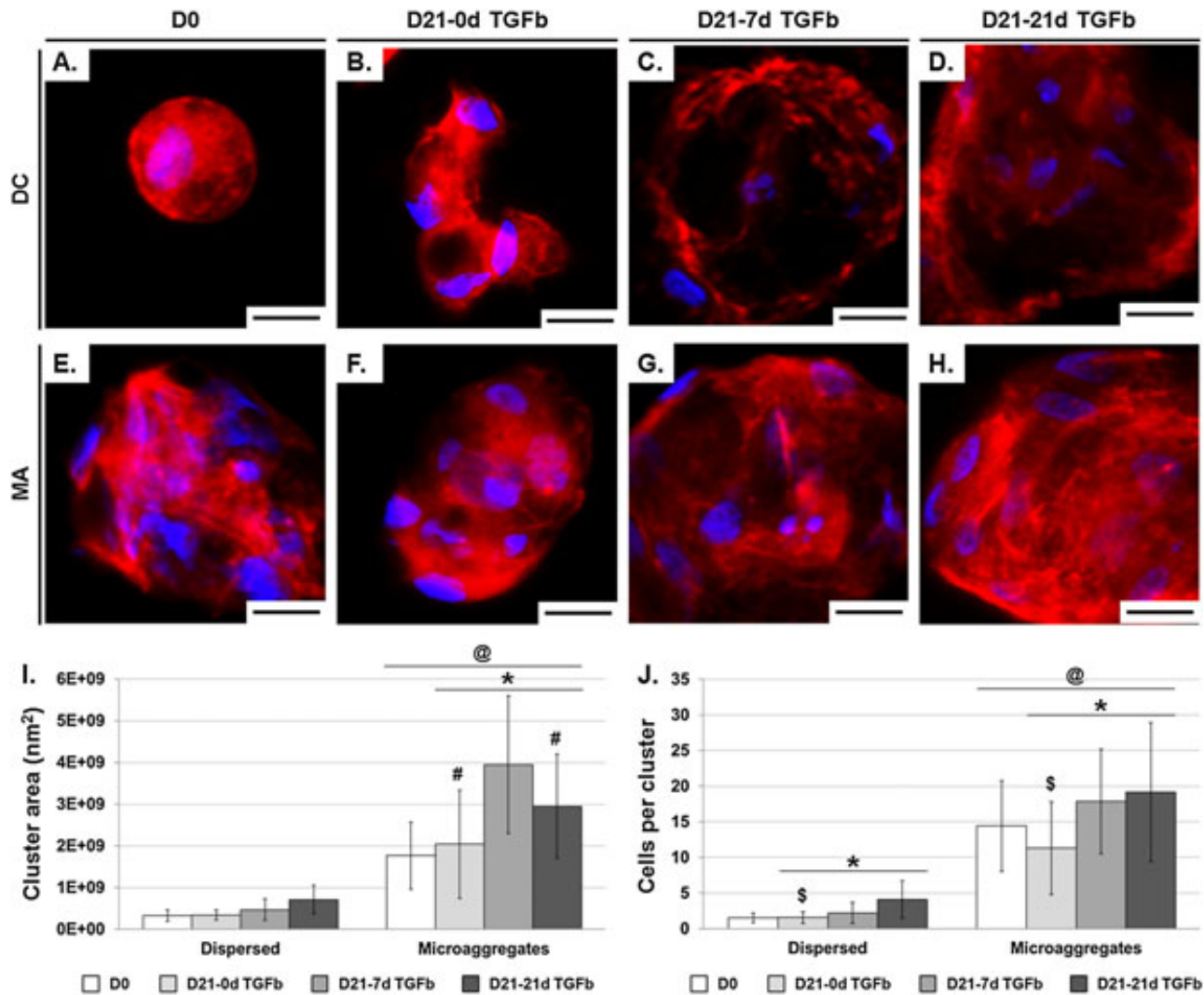

Figure 3. Cell morphology. (A-H) Bovine BMSCs seeded in alginate beads as dispersed cells (A-D) or micro-aggregates (E-H) at day 0 (A, E) and day 21 after exposure to TGF $\beta_{3}$ for 0 (B, F), 7 (C, G) and 21 (D, H) days. The beads were cryosectioned, fixed and stained with phalloidin (red fluorescence) for F-actin filaments and counterstained with DAPI (blue fluorescence) for cell nuclei; representative of three donors/group; scale bar $=20 \mu \mathrm{m}$; colour images available online. (I, J) Morphometric analysis: area covered by cells or clusters (I) and cell number/cluster (J) were determined by image analysis; values are mean \pm SD; $n=25$ clusters/cells analysed/ group. " $p<0.05$ vs D0; ${ }^{\#} p<0.05$ vs 7 days of TGF $\beta_{3}$ treatment; ${ }^{\$} p<0.05$ vs 21 days of TGF $\beta_{3}$ treatment; ${ }^{@} p<0.05$ vs dispersed cells

(days 0,7 and 21) and their interactions on the variables DNA and GAG/DNA contents, and sox9, type II collagen, aggrecan, $T G F \beta$, type $\mathrm{X}$ collagen and $s p 7$ gene expression. In all analyses, full factorial models were fitted to the data and then a backwards stepwise procedure was used to remove the non-significant effects. For each significant effect, a Tukey-HSD post hoc test was conducted; $p<0.05$ was considered significant. All data analyses were performed in $\mathrm{R} v$. 2.9.0 (R Development Core Team, 2009).

\section{Results}

\subsection{Cell viability and proliferation}

BMSCs showed high cell viability after seeding for all conditions (Figure 2A, E). At day 0, cells appeared as a well-dispersed cell population for DC conditions (Figure 2A) or as dense micro-aggregates for MA conditions (Figure 2E). However, some dead cells could be observed around the micro-aggregates (Figure 2E), most likely due to a higher shear stress exerted on micro-aggregates than dispersed cells when producing the alginate beads. At day 21, cell viability remained high for all conditions (Figure 2B-D, F-H). DNA content confirmed that cells proliferated (Figure 2I). DC conditions, however, led to higher proliferation than MA conditions.

\subsection{Cell morphology and adhesion}

At day 0 , the DC condition led to single dispersed cells (Figure 3A, I), while MA resulted in large clusters (Figure 3E, I) containing, on average, 14 cells (Figure 3J). In DC conditions, after 21 days of culture BMSCs proliferated (Figure 3J) and formed clusters (Figure 3B-D) whose size increased when TGF $\beta$ was added, although not significantly (Figure 3I). In MA conditions (Figure 3F-H), micro-aggregates grew during culture, with the bigger clusters observed for 7 days of TGF $\beta$ (Figure 3I), although cell proliferation was limited (Figure 3J).

At day 0, cell-cell interactions were more developed in MA than in DC, as shown by the immunostaining of pancadherins (Figure 4D and A, respectively), which are glycoproteins involved in cell-cell adhesion. These improved cell-cell interactions, however, disappeared after 3 weeks of culture (Figure 4E). TGF $\beta$ treatment had no effects on cadherin expression for either DC or MA (data not shown). Regarding vinculin, a membrane-cytoskeletal protein involved in cell-matrix adhesion, its expression was similar for DC and MA (Figure 4G and J, 


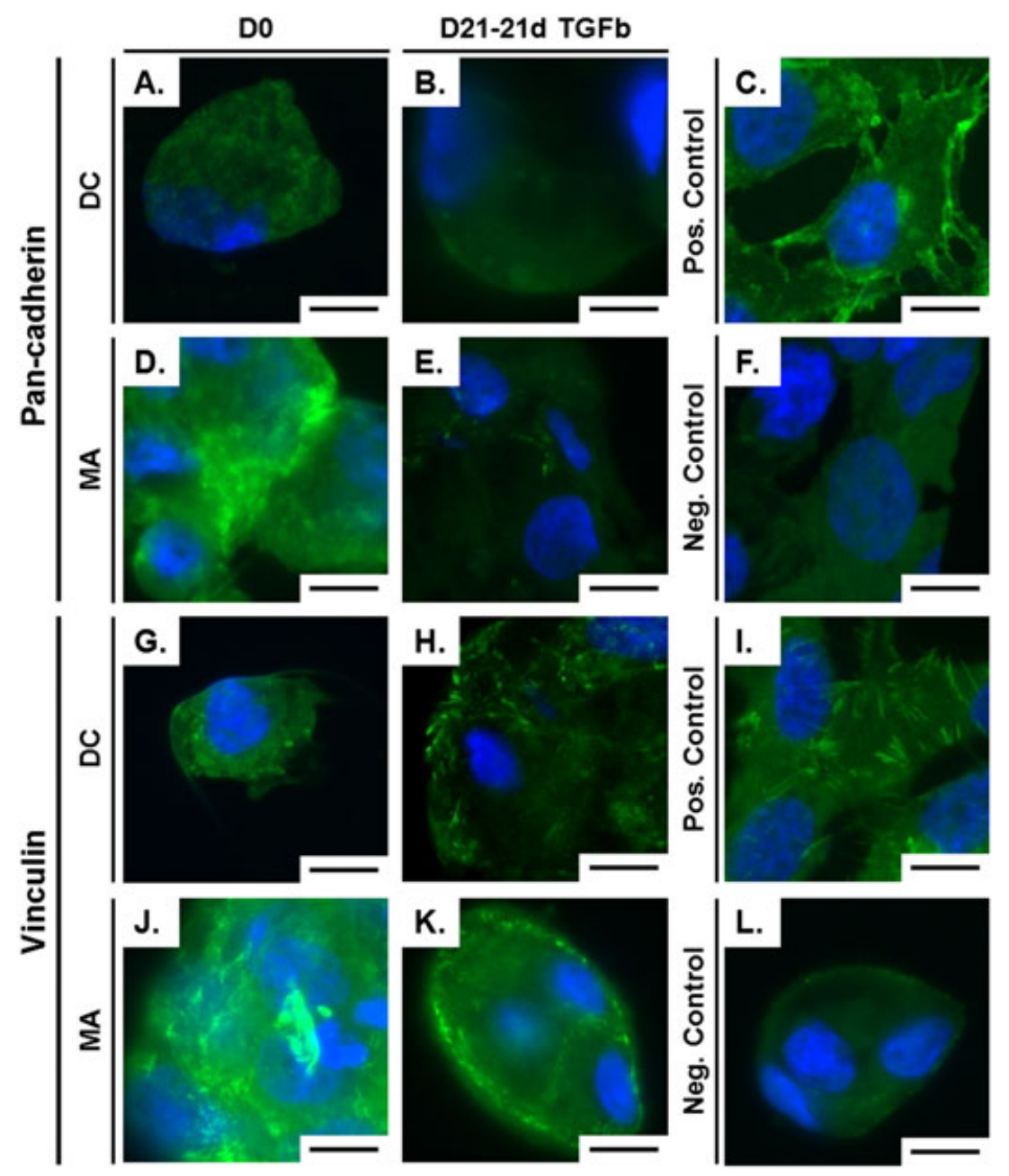

Figure 4. Cell adhesion. (A-F) Bovine BMSCs seeded in alginate beads as dispersed cells (A, B) or as micro-aggregates (D, E) at day 0 (A, D) and after 21 days of exposure to $\operatorname{TGF} \beta_{3}(\mathrm{~B}, \mathrm{E})$. The beads were cryosectioned, fixed and stained with anti-pan-cadherin (green fluorescence) and counterstained with DAPI (blue fluorescence) for cell nuclei. Human cardiomyocyte progenitor cells were used as positive controls (C) and experimental samples for secondary antibody negative control (F). (G-L) Bovine BMSCs seeded in alginate beads as dispersed cells $(\mathrm{G}, \mathrm{H})$ or as micro-aggregates $(\mathrm{J}, \mathrm{K})$ at day $0(\mathrm{G}, \mathrm{I})$ and after 21 days of exposure to TGF $\beta_{3}(\mathrm{H}, \mathrm{K})$. Beads were cryosectioned, fixed and stained with anti-vinculin (green fluorescence) and counterstained with DAPI (blue fluorescence) for cell nuclei. Human cardiomyocyte progenitor cells were used as positive controls (I) and experimental samples for secondary antibody negative control (L); representative of three donors/group; scale bar $=10 \mu \mathrm{m}$; colour images available online

respectively), with a dispersed localization of vinculin through the cell surface. At day 21, vinculin condensed in focal adhesions. Distribution seemed similar for DC and MA (Figure $4 \mathrm{H}$ and $\mathrm{K}$, respectively), and was not influenced by the different TGF $\beta$ stimulation patterns (data not shown).

\subsection{Matrix production}

In all conditions, proteoglycans (PGs) were deposited (Figure 5A-H), demonstrating successful chondrogenic differentiation of the BMSCs. For both DC and MA conditions, prolonging exposure to TGF $\beta$ increased the PG production, as confirmed by a quantitative assay (Figure 5I). However, no differences between DC and MA could be detected. In both conditions, PGs appeared to be concentrated within the clusters (for DC) or the micro-aggregates (for MA), filling the void spaces previously observed.

\subsection{Gene expression}

Levels of gene expression of chondrogenic markers (sox9, a transcription factor involved in early chondrogenesis; type II collagen and aggrecan, both main components of cartilage matrix) increased at day 21 for all conditions (Figure 6A-C). In MA conditions, however, type II collagen and aggrecan mRNA expression were inhibited compared to DC conditions at day 21 (Figure 6B, C). Seven days of TGF $\beta$ treatment led to the highest levels of expression of all chondrogenic markers for both MA and DC conditions (Figure 6A-C). At day 0, MA upregulated TGF $\beta$ gene expression compared to DC, but this high level of expression disappeared at day 21 under all TGF $\beta$ stimulation conditions (Figure 6D). 

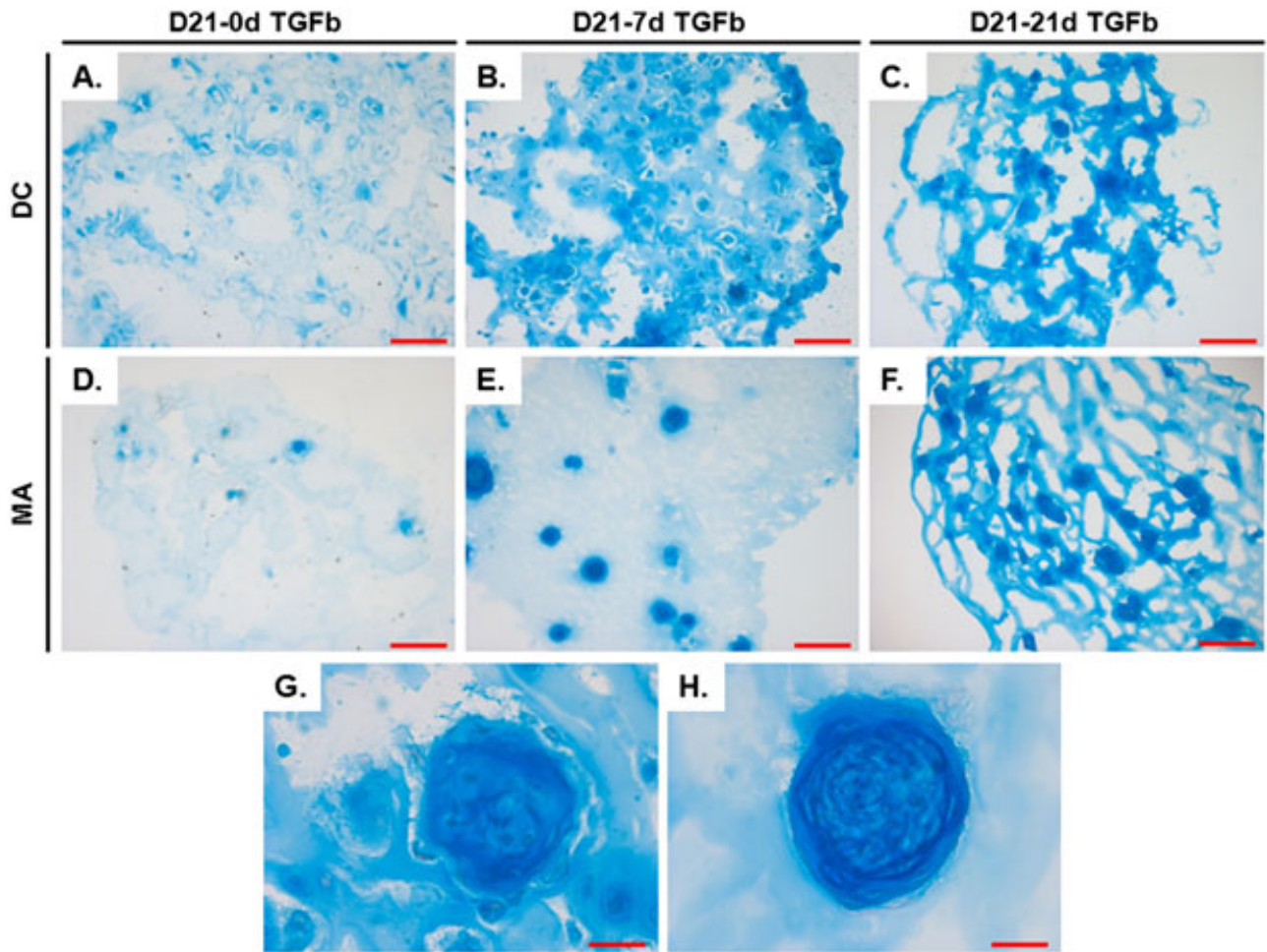

I.

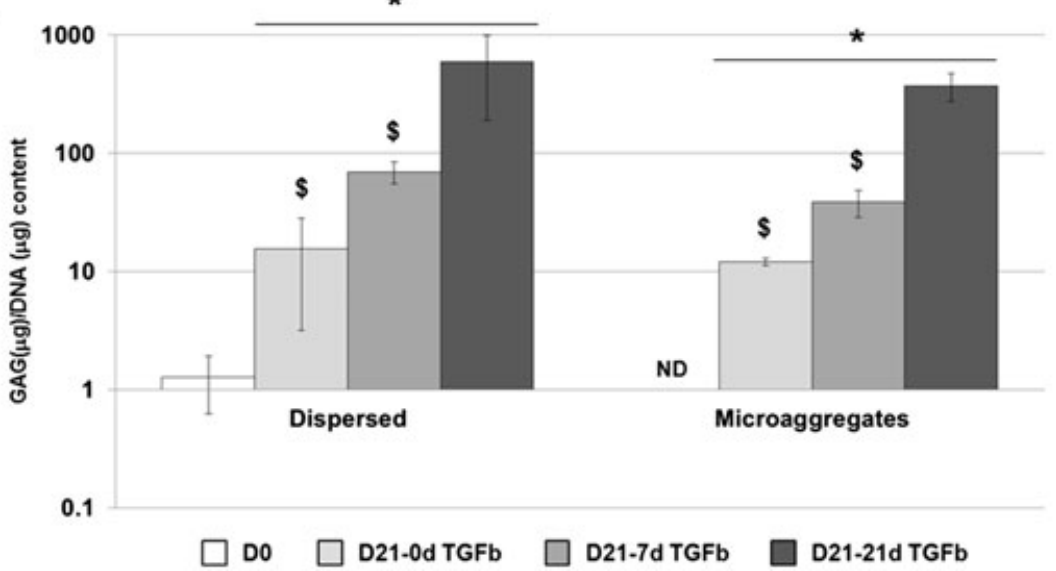

Figure 5. Matrix production. (A-F) Bovine BMSCs seeded in alginate beads as dispersed cells (A-C) or as micro-aggregates (D-F) at day 21 after exposure to TGF $\beta_{3}$ for 0 (A, D), 7 (B, E) and 21 (C, F) days. Beads were cryosectioned, fixed and stained with Alcian blue for proteoglycans (note that light blue is alginate); representative of three donors/group; scale bar $=200 \mu \mathrm{m}$. (G, H) Higher magnifications of (B, E), respectively; scale bar $=50 \mu \mathrm{m}$; colour images available online. (I) GAG/DNA content after 21 days of culture, as determined with DMMB and Hoechst dye assays, respectively. Values are mean \pm SD (NB: logarithmic $y$ axis, and error bars are also logarithmic); $n=3$ /group; * $p<0.05$ vs D0; ${ }^{\$} p<0.05$ vs 21 days of TGF $\beta_{3}$ treatment; ND, not detected

\subsection{Transient $\operatorname{TGF} \beta$ stimulation}

For the 7 days of TGF $\beta$ treatment, chondrogenic marker gene expression and matrix production were also evaluated at day 7. The results showed that BMSCs had already started to differentiate at that point. All chondrogenic markers (sox9, aggrecan, type II collagen) were already highly upregulated at the gene levels (Figure 7B-D). PGs were also produced at day 7 (Figure 7A), but to a limited amount. PG content and type II collagen expression were significantly higher at day 21 than at day 7, indicating that the cells were still going along the chondrogenic pathway although TGF $\beta$ was withdrawn.

\subsection{Hypertrophy and osteogenic differentiation}

Both type $\mathrm{X}$ collagen (Figure 8A), an indicator of chondrocyte hypertrophy, and $s p 7$ (Figure $8 \mathrm{~B}$ ), a transduction factor involved in early osteogenesis, mRNA expressions increased at day 21 for the DC condition, while only type $\mathrm{X}$ collagen expression increased in the MA condition. For both conditions and genes, the highest level of expression at day 21 was for the 7 days of TGF $\beta$ treatment. When type $\mathrm{X}$ collagen levels of expression were similar for MA and DC conditions, sp7 mRNA expression was upregulated at day 0 for the MA condition (Figure 8B). 


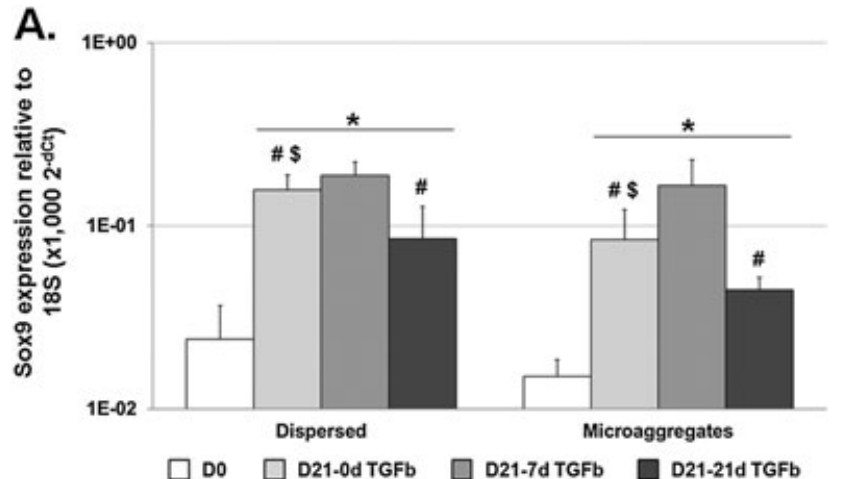

B.
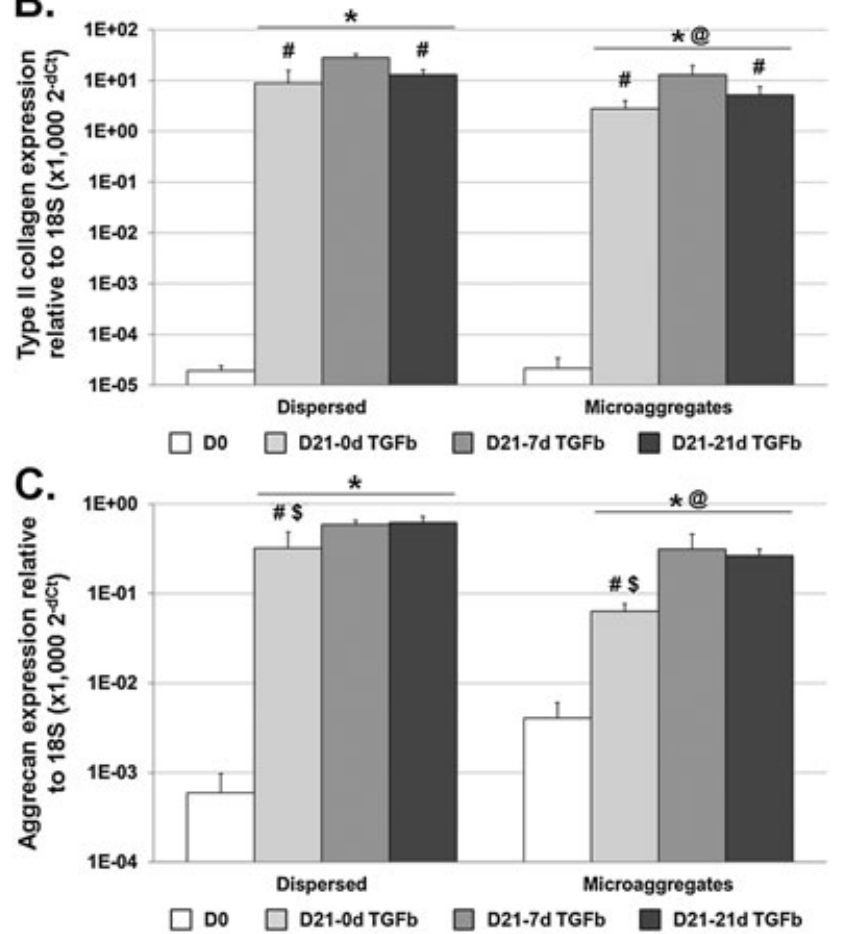

D. ${ }_{1 E+00}$

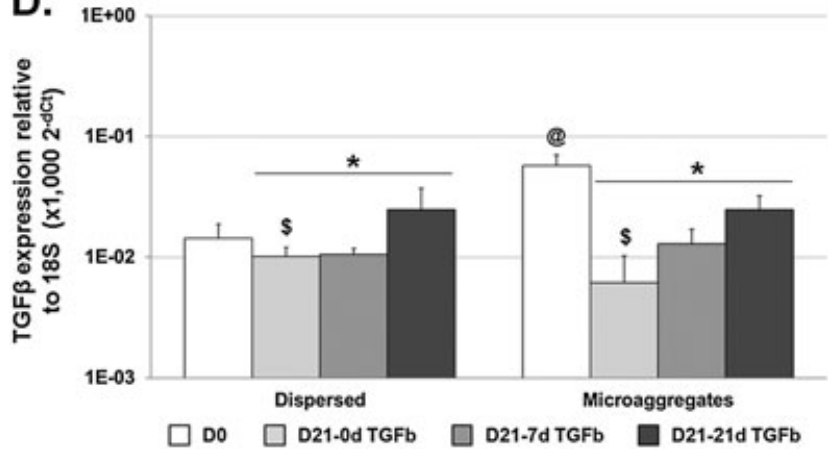

Figure 6. Gene expression - chondrogenesis markers. Gene expression of sox9 (A), type II collagen (B), aggrecan (C) and TGF $\beta$ (D), as determined by qRT-PCR. Expression is relative to $18 \mathrm{~S}$ reference gene $\left(2^{-4 C \mathrm{~T}}\right.$ method). Values are mean $+\mathrm{SD}$ (NB: logarithmic $y$ axis, and error bars are also logarithmic); $n=3$ /group; * $p<0.05$ vs D0; ${ }^{\#} p<0.05$ vs 7 days of TGF $\beta_{3}$ treatment; ${ }^{\$} p<0.05$ vs 21 days of TGF $\beta_{3}$ treatment; ${ }^{\circledR} p<0.05$ vs dispersed cells

\section{Discussion}

In summary, these results show that BMSCs underwent (partial) chondrogenic differentiation for all conditions tested (PG production and increased chondrogenic marker expression). MA, however, did not perform better (matrix production) or even as well (gene expression) as DC under all the TGF $\beta$ stimulation patterns tested. Nonetheless, these data show that small micro-aggregates can be successfully integrated into hydrogel (alginate). Although cell death was slightly upregulated at day 0 (Figure 2E), BMSCs in MA survived up to 21 days (Figure 2) and differentiated into chondrocytes, with the deposition of a PG-rich matrix within the MA (Figure 5H) and substantial upregulation of sox9, type II collagen and aggrecan gene expression (Figure 6A-C).

Increase of TGF $\beta$ gene expression at day 0 in MA compared to DC (Figure 6D) suggests an early stimulant effect of MA, maybe due to improved juxtacrine signalling (cell-cell contact) rather than paracrine signalling (limited distance between neighbouring cells), as cell-cell contact was improved at day 0 in the MA conditon, as shown by pan-cadherin staining. This upregulation, however, was lost at day 21 and, more importantly, was not translated into enhanced chondrogenic matrix production (Figure 5) or gene expression (Figure 6), even if no exogenous TGF $\beta$ was added. One explanation for this absence of effects may be the disappearance, during the 3 weeks of culture, of the cell-cell interactions observed at day 0 (Figure 4). BMSCs in MA most likely lost contact with each other (as shown by pan-cadherin staining) due to extracellular matrix production between the cells, but formed new junctions (as shown by vinculin staining) with this matrix (Figure 5). The lack of effects of TGF $\beta$ gene expression upregulation may also been explained by a low translation efficiency or by post-transcriptional regulatory mechanisms. Several studies comparing genomic and proteomic analyses report, indeed, moderate correlation between mRNA and protein expression (Chen et al., 2002; Huber et al., 2004; Oberemm et al., 2009; Tian et al., 2004). Another explanation for the absence of effects of upregulated TGF $\beta$ expression might be that BMSCs are not sensitive to the levels of TGF $\beta$ they are producing, either because these levels are too low or because BMSCs are less sensitive in MA. Cytoskeleton organization, indeed, has been shown to modulate cell sensitivity to TGF $\beta$. Disorganization of the microfilaments in rabbit articular chondrocytes after treatment with dihydrocytochalasin B enhanced the sensitivity of the cells to TGF $\beta$ (increased PG and collagen synthesis) (Benya and Padilla, 1993). In the present study, BMSCs at day 0 displayed more organized microfilaments in MA cells than in the round cells of the DC condition (Figure 3A/E). This difference in cytoskeleton organization may also explain why MA are not upregulating chondrogenic gene expression as well as DC under transient and continuous TGF $\beta$ treatment (Figure 6). Although no significant differences were observed at the matrix level (Figure 5), our data support results observed with bovine articular chondrocytes in hydrogel, where small micro-aggregates (5-18 cells) inhibit chondrocyte biosynthesis compared to dispersed cells (Albrecht et al., 2006). Distribution of PGs, however, was quite distinct between the two conditions, 
A.
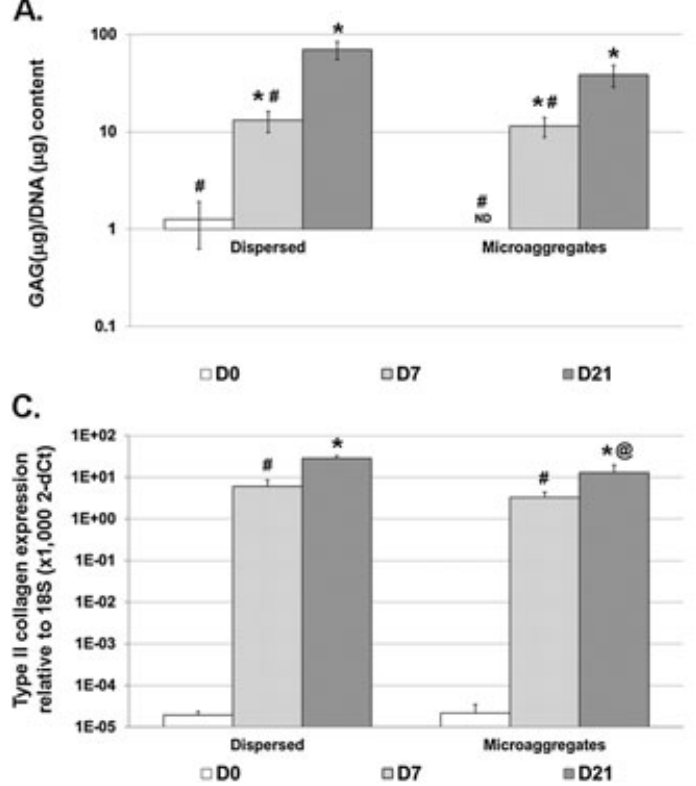

B.

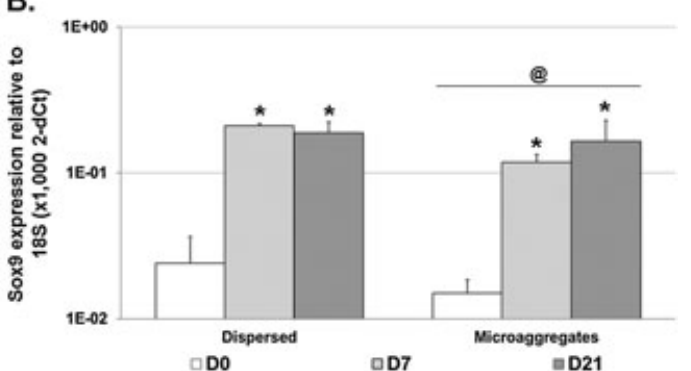

D.

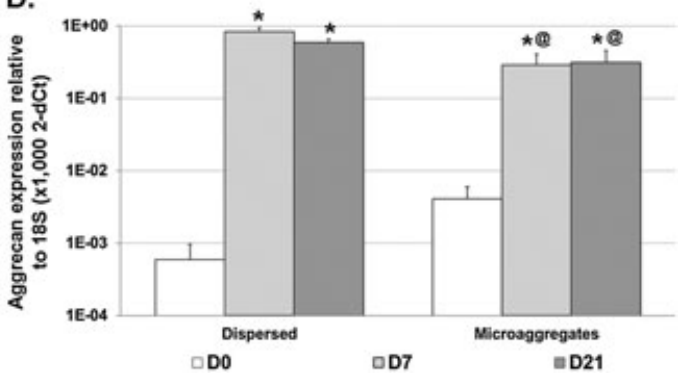

Figure 7. Transient TGF $\beta$ stimulation. (A) GAG/DNA content at days 0, 7 and 21, as determined with DMMB and Hoechst dye assays, respectively; values are mean \pm SD (NB: logarithmic $y$ axis, and error bars are also logarithmic). (B-D) Gene expression of sox9 (B), type II collagen (C) and aggrecan (D), as determined by qRT-PCR; expression is relative to $18 S$ reference gene $\left(2^{-4 C \mathrm{~T}}\right.$ method). Values are mean + SD (NB: logarithmic $y$ axis, and error bars are also logarithmic); $n=3$ /group; ${ }^{*} p 0.05$ vs D0; ${ }^{*} p<0.05$ vs D21; ${ }_{p}<0.05$ vs dispersed cells; ND, not detected

A.

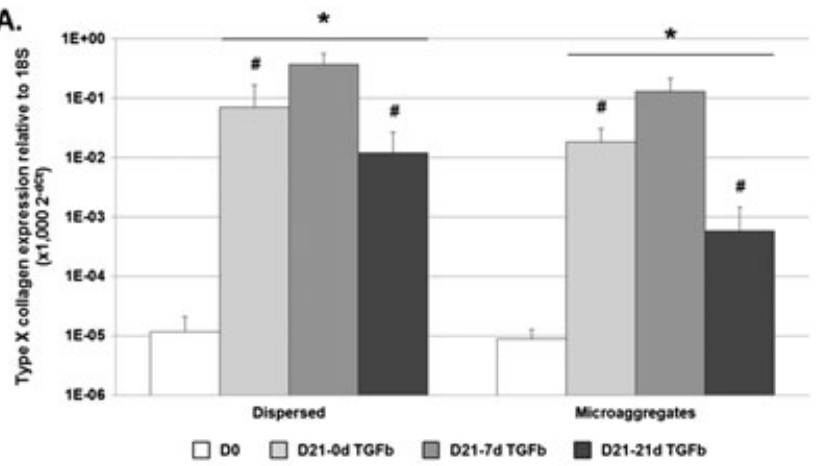

B.

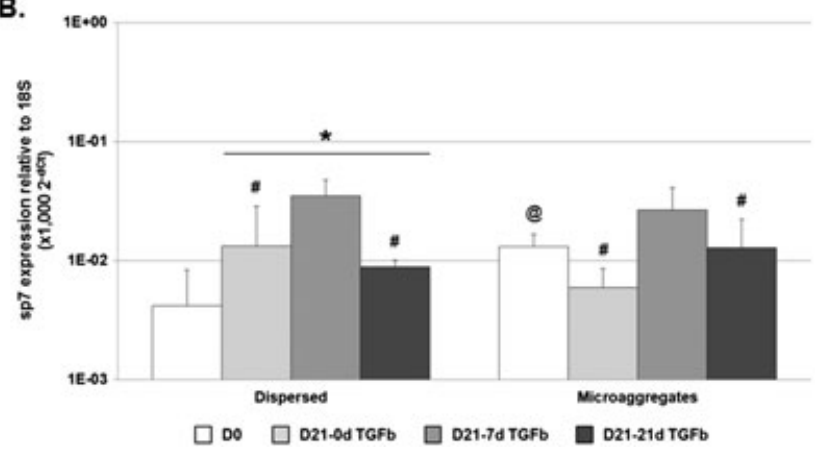

Figure 8. Gene expression - Hypertrophy and osteogenesis markers. Gene expression of type X collagen (A) and sp7 (B), as determined by qRT-PCR; expression is relative to $18 \mathrm{~S}$ reference gene $\left(2^{-4 \mathrm{CT}}\right.$ method). Values are mean $+\mathrm{SD}$ (NB: logarithmic $y$ axis, and error bars are also logarithmic); ${ }^{*} p<0.05$ vs D0; ${ }^{\#} p 0.05$ vs 7 days of TGF $\beta_{3}$ treatment; ${ }^{\circledR} p<0.05$ vs dispersed cells

with a more evenly distributed matrix for DC (Figure 5). As the cell concentration was similar at day 0 for both conditions, DC resulted in a more dispersed and homogeneous distribution of cells (Figure 2), which could account for a more even distribution of the matrix produced by the BMSCs.

Still, MA might be more potent for the osteogenic differentiation of BMSCs. In fact, MA (not embedded into a hydrogel) have already been shown to promote osteogenic differentiation of human BMSCs compared to 2D culture (increased calcium deposition and osteogenic gene expression) (Kabiri et al., 2012). In the present study, we observed an upregulation of $s p 7$, a transcription factor involved in early osteogenic differentiation, in MA at day 0 compared to DC (Figure 8). This suggests a positive influence of the MA on the osteogenic differentiation pathway. The absence of factors required for osteogenic differentiation, such as FBS or $\beta$-glycerophosphate, during culture, however, probably nullifies this influence, and additional experiments need to be conducted to assess the potential of MA to promote BMSC osteogenesis.

Contrary to MA, BMSCs in the DC condition proliferated during the 3 weeks of culture. This absence of significant proliferation in MA already containing several cells (Figure 3) may be explained by contact inhibition present in the MA but not in the DC. At day 21, cloned DC spontaneously formed clusters. Although these structures appeared similar to the MA, they were smaller and contained fewer cells (Figure 3). Recreating and amplifying this natural process of cloning and clustering in the MA, however, did not exert any substantial effect on BMSC differentiation, suggesting that cell-cell interactions are not required for initiating chondrogenesis.

These results also confirm that bovine BMSCs can spontaneously differentiate toward the chondrogenic lineage without the presence of TGF $\beta$ (PG production and increased sox9, type II collagen and aggrecan gene expression; Figures 5-7) when cultured in hydrogel and 
serum-free conditions, as previously reported for bovine BMSCs in micromass culture (Bosnakovski et al., 2006). Seven days of TGF $\beta$ treatment were enough to enhance the production of cartilaginous matrix, as shown previously with human BMSCs (Buxton et al., 2011), but, surprisingly, gave the highest upregulation of chondrogenic marker expression (Figure 6) for both MA and DC. However, the transient TGF $\beta$ stimulation also led to higher expression of type $\mathrm{X}$ collagen (a marker of chondrocyte hypertrophy). Hence, continuous stimulation with TGF $\beta$ resulted in a more stable chondrogenic phenotype; it also led to the highest matrix production (Figure 5).

Conclusions on the (absence of) effects of MA on BMSC chondrogenesis, however, are only valid for the cell concentration and hydrogel tested here. Using a lower concentration may dilute paracrine signalling in the DC condition and, therefore, diminish the chondrogenic differentiation of BMSCs. Buxton et al. (2011) have already evaluated the influence of cell concentration on the chondrogenesis of BMSCs seeded into a hydrogel. They reported a maximal $\mathrm{PG} /$ collagen synthesis/cell for concentrations in the range 12.5-25 million cells $/ \mathrm{ml}$. Lower concentrations led to lower matrix production, indicating the involvement of paracrine signalling in BMSC chondrogenesis. With the concentration used here (7 million cells $/ \mathrm{ml})$, paracrine signalling should be diluted in the DC condition and so MA could have a beneficial effect by locally increasing this paracrine signalling. As no positive effect was found for the MA, it seems that cellcell contact or cytoskeleton organization have a stronger negative effect than paracrine signalling, a positive one for BMSC chondrogenesis. Moreover, the effect of MA on BMSC chondrogenesis has only been tested here in alginate and could, therefore, be an artifact of that system. The previous observation, that micro-aggregates inhibit chondrogenesis of bovine chondrocytes seeded in photo-polymerizable hydrogel (Albrecht et al., 2006) when compared to dispersed cells, tends to indicate, however, that the negative effects observed here were not an artifact of alginate.

Another limitation of the study may be the use of exogenous TGF $\beta$ if it is the endogenous molecular agent involved in juxtacrine signalling. In this case, adding $\mathrm{TGF} \beta$ to the culture medium may have overpowered any increase of TGF $\beta$ expression present in MA, but not in DC, conditions. Such a beneficial effect, however, should have been observed when the BMSCs were cultured without exogenous TGF $\beta$, when no differences between MA and DC were observed (Figures 5, 6, 0 days TGF $\beta$ group). Nonetheless, if TGF $\beta$ had been involved in cellular signalling after BMSC differentiation, bone morphogenic protein 2 (BMP2) could have been used to induce BMSC chondrogenic differentiation instead (Schmitt et al., 2003).

This study provides important clues about the communication of BMSCs with their environment, where cell-cell interaction seems to have a limited involvement in their (chondrogenic) differentiation. Although DC cloned and spontaneously formed clusters, accelerating and amplifying this process with the MA did not provide beneficial effects. This suggests that influencing cell-matrix, rather than cell-cell, interactions may be a more potent tool to control BMSC differentiation, at least for the chondrogenic pathway.

To conclude, this study shows that micro-aggregates, although potentially promoting cell-cell contacts and improving paracrine signalling, have no beneficial effects on bovine BMSC chondrogenesis in alginate.

\section{Conflict of interest}

The authors have no financial interest in the subject matter discussed in this paper.

\section{Acknowledgements}

The authors would like to thank R. R. Delcher for his help with statistical analysis and Marina van Doeselaar for immunostainings. The authors did not receive financial support or benefits from any commercial source related to the scientific work reported in this manuscript.

\section{References}

Ahmed TA, Hincke MT. 2010; Strategies for articular cartilage lesion repair and functional restoration. Tissue Eng $B$ Rev 16: 305-329.

Albrecht DR, Underhill GH, Wassermann TB, et al. 2006; Probing the role of multicellular organization in threedimensional microenvironments. Nat Methods 3: 369-375.

Augello A, De BC. 2010; The regulation of differentiation in mesenchymal stem cells. Hum Gene Ther 21: 1226-1238.

Barry F, Boynton RE, Liu B, et al. 2001; Chondrogenic differentiation of mesenchymal stem cells from bone marrow: differentiation-dependent gene expression of matrix components. Exp Cell Res 268: 189-200.
Benya PD, Padilla SR. 1993; Dihydrocytochalasin B enhances transforming growth factor- $\beta$-induced re-expression of the differentiated chondrocyte phenotype without stimulation of collagen synthesis. Exp Cell Res 204: 268-277.

Bobick BE, Chen FH, Le AM, et al. 2009; Regulation of the chondrogenic phenotype in culture. Birth Defects Res C Embryo Today 87: 351-371.

Bosnakovski D, Mizuno M, Kim G, et al. 2006; Gene expression profile of bovine bone marrow mesenchymal stem cell during spontaneous chondrogenic differentiation in pellet culture system. Jpn $J$ Vet Res 53: 127-139.

Buxton AN, Bahney CS, Yoo JU, et al. 2011; Temporal exposure to chondrogenic factors modulates human mesenchymal stem cell chondrogenesis in hydrogels. Tissue Eng A 17: 371-380.

Cesarone CF, Bolognesi C, Santi L. 1979; Improved microfluorometric DNA determination in biological material using 33258 Hoechst. Anal Biochem 100: 188-197.

Chen G, Gharib TG, Huang CC, et al. 2002; Discordant protein and mRNA expression in lung adenocarcinomas. Mol Cell Proteom 1: 304-313.

Dudics V, Kunstar A, Kovacs J, et al. 2009; Chondrogenic potential of mesenchymal stem cells from patients with rheumatoid arthritis and osteoarthritis: measurements in a microculture system. Cells Tissues Organs 189: 307-316. 
Engler AJ, Sen S, Sweeney HL, et al. 2006; Matrix elasticity directs stem cell lineage specification. Cell 126: 677-689.

Enobakhare BO, Bader DL, Lee DA. 1996; Quantification of sulfated glycosaminoglycans in chondrocyte/alginate cultures, by use of 1,9-dimethylmethylene blue. Anal Biochem 243: 189-191.

Friedenstein AJ, Chailakhjan RK, Lalykina KS. 1970; The development of fibroblast colonies in monolayer cultures of guineapig bone marrow and spleen cells. Cell Tissue Kinet 3: 393-403.

Gregory CA, Prockop DJ, Spees JL. 2005; Non-hematopoietic bone marrow stem cells: molecular control of expansion and differentiation. Exp Cell Res 306: 330-335.

Guo JF, Jourdian GW, MacCallum DK. 1989 ; Culture and growth characteristics of chondrocytes encapsulated in alginate beads. Connect Tissue Res 19: 277-297.

Guo X, Wang C, Zhang Y, et al. 2004; Repair of large articular cartilage defects with implants of autologous mesenchymal stem cells seeded into $\beta$-tricalcium phosphate in a sheep model. Tissue Eng 10: 1818-1829.

Halleux C, Sottile V, Gasser JA, et al. 2001; Multi-lineage potential of human mesenchymal stem cells following clonal expansion. $J$ Musculoskelet Neuronal Interact 2: 71-76.

Huber M, Bahr I, Kratzschmar JR, et al. 2004; Comparison of proteomic and genomic analyses of the human breast cancer cell line T47D and the anti-estrogen-resistant derivative T47D-r. Mol Cell Proteom 3: 43-55.

Johnstone B, Hering TM, Caplan AI, et al. 1998; In vitro chondrogenesis of bone marrow-derived mesenchymal progenitor cells. Exp Cell Res 238: 265-272.

Jonitz A, Lochner K, Peters K, et al. 2011; Differentiation capacity of human chondrocytes embedded in alginate matrix. Connect Tissue Res 52: 503-511.

Kabiri M, Kul B, Lott WB, et al. 2012; 3D mesenchymal stem/stromal cell osteogenesis and autocrine signalling. Biochem Biophys Res Commun 419: 142-147.

Karcher EL, Beitz DC, Stabel JR. 2008; Modulation of cytokine gene expression and secretion during the periparturient period in dairy cows naturally infected with $\mathrm{Myco}$ bacterium avium subsp. paratuberculosis. Vet Immunol Immunopathol 123: 277-288.

Khan WS, Johnson DS, Hardingham TE. 2010; The potential of stem cells in the treatment of knee cartilage defects. Knee 17: 369-374.

Kon E, Muraglia A, Corsi A, et al. 2000; Autologous bone marrow stromal cells loaded onto porous hydroxyapatite ceramic accelerate bone repair in critical- size defects of sheep long bones. $J$ Biomed Mater Res 49: 328-337.

Krampera M, Pizzolo G, Aprili G, et al. 2006; Mesenchymal stem cells for bone, cartilage, tendon and skeletal muscle repair. Bone 39: 678-683.

Mackay AM, Beck SC, Murphy JM, et al 1998; Chondrogenic differentiation of cultured human mesenchymal stem cells from marrow. Tissue Eng 4: 415-428.

Markway BD, Tan GK, Brooke G, et al. 2010 Enhanced chondrogenic differentiation of human bone marrow-derived mesenchymal stem cells in low oxygen environment micropellet cultures. Cell Transpl 19: 29-42.

Matsumoto T, Okabe T, Ikawa T, et al 2010; Articular cartilage repair with autologous bone marrow mesenchymal cells. J Cell Physiol 225: 291-295.

Muraglia A, Cancedda R, Quarto R. 2000; Clonal mesenchymal progenitors from human bone marrow differentiate in vitro according to a hierarchical model. $J$ Cell Sci 113: 1161-1166.

Murdoch AD, Grady LM, Ablett MP, et al. 2007; Chondrogenic differentiation of human bone marrow stem cells in transwell cultures: generation of scaffold-free cartilage. Stem Cells 25: 2786-2796.

Murphy JM, Dixon K, Beck S, et al. 2002; Reduced chondrogenic and adipogenic activity of mesenchymal stem cells from patients with advanced osteoarthritis. Arthritis Rheum 46: 704-713.

Nejadnik H, Hui JH, Feng Choong EP, et al. 2010; Autologous bone marrow-derived mesenchymal stem cells versus autologous chondrocyte implantation: an observational cohort study. Am J Sports Med 38: 1110-1116.

Nesic D, Whiteside $\mathrm{R}$, Brittberg $\mathrm{M}$, et al. 2006; Cartilage tissue engineering for degenerative joint disease. Adv Drug Deliv Rev 58: 300-322.

Oberemm A, Ahr HJ, Bannasch P, et al. 2009; Toxicogenomic analysis of $\mathrm{N}$-nitrosomorpholine induced changes in rat liver: comparison of genomic and proteomic responses and anchoring to histopathological parameters. Toxicol Appl Pharmacol 241: 230-245.

Pek YS, Wan AC, Ying JY. 2010; The effect of matrix stiffness on mesenchymal stem cell differentiation in a 3D thixotropic gel. Biomaterials 31: 385-391.

Pittenger MF, Mackay AM, Beck SC, et al. 1999; Multilineage potential of adult human mesenchymal stem cells. Science 284: 143-147.

Potier E, Ferreira E, Andriamanalijaona R, et al. 2007; Hypoxia affects mesenchymal stromal cell osteogenic differentiation and angiogenic factor expression. Bone 40: 1078-1087.

Potier E, Noailly J, Ito K. 2010; Directing bone marrow-derived stromal cell function with mechanics. $J$ Biomech 43: 807-817.

Prockop DJ. 1997; Marrow stromal cells as stem cells for nonhematopoietic tissues. Science 276: 71-74.

Rivron NC, Vrij EJ, Rouwkema J, et al. 2012; Tissue deformation spatially modulates VEGF signaling and angiogenesis. Proc Natl Acad Sci USA 109: 6886-6891.

Sanz-Ramos P, Mora G, Vicente-Pascual M, et al. 2013; Response of sheep chondrocytes to changes in substrate stiffness from 2 to 20 Pa: effect of cell passaging. Connect Tissue Res 54: 159-166.

Scharstuhl A, Schewe B, Benz K, et al. 2007; Chondrogenic potential of human adult mesenchymal stem cells is independent of age or osteoarthritis etiology. Stem Cells 25: 3244-3251.

Schmitt B, Ringe J, Haupl T, et al. 2003; BMP2 initiates chondrogenic lineage development of adult human mesenchymal stem cells in high-density culture. Differentiation 71: 567-577.

Schuh E, Kramer J, Rohwedel J, et al. 2010; Effect of matrix elasticity on the maintenance of the chondrogenic phenotype. Tissue Eng A 16: 1281-1290.

Shintani N, Kurth T, Hunziker EB. 2007; Expression of cartilage-related genes in bovine synovial tissue. J Orthop Res 25: 813-819.

Tang J, Peng R, Ding J. 2010; The regulation of stem cell differentiation by cell-cell contact on micropatterned material surfaces. Biomaterials 31: 2470-2476.

Tian Q, Stepaniants SB, Mao M, et al. 2004; Integrated genomic and proteomic analyses of gene expression in mammalian cells. Mol Cell Proteom 3: 960-969.

Uematsu K, Hattori K, Ishimoto Y, et al. 2005; Cartilage regeneration using mesenchymal stem cells and a three-dimensional polylactic-glycolic acid (PLGA) scaffold. Biomaterials 26: 4273-4279.

van Dijk BGM, Potier E, Ito K. 2011; Culturing bovine nucleus pulposus explants by balancing medium osmolarity. Tiss Eng $C$ 17: 1089-1096.

Wakitani S, Imoto K, Yamamoto $\mathrm{T}$, et al 2002; Human autologous culture expanded bone marrow mesenchymal cell transplantation for repair of cartilage defects in osteoarthritic knees. Osteoarthr Cartilage 10: 199-206.

Zeiter S, Lezuo P, Ito K. 2009; Effect of TGF- $\beta$ 1, BMP-2 and hydraulic pressure on chondrogenic differentiation of bovine bone marrow mesenchymal stromal cells. Biorheology 46: 45-55. 